\title{
USE OF SINGLE LAYER CONCRETE ARMOUR UNITS AS TOE REINFORCEMENT
}

\author{
Martin Young ${ }^{1}$, John Hayman-Joyce ${ }^{2}$, Seok Hyeon Kim³
}

\begin{abstract}
Detailing and optimization of the toe reinforcement is presented as a case study from the construction of the $5.2 \mathrm{~km}$ long main breakwater for the new Colombo South Harbour in $18 \mathrm{~m}$ water depth. During the breakwater design the environmental constraints on supply of large rock armour were recognized, and CORE-LOC ${ }^{\text {TM }}$ single layer concrete armour units were selected for the primary armour protection. During construction, supply of relatively small quantities of 8-12t rock for use in the toe reinforcement became an issue, and use of CORE-LOC ${ }^{\text {TM }}$ units placed on the flat rock armour apron as an alternative to rock armour toe reinforcement was investigated and implemented. This use is unusual as there is no in-plane compression between units as found when they are placed on the slope. A site based prototype scale trial was conducted to evaluate placing method and criteria, and an "alternate opposing cannon" pattern placement, in rows going seaward from the primary armour, was successful. Packing density and unit spacing is the same as for the primary armour. Hydraulic stability of this alternative toe reinforcement was verified in $2 \mathrm{D}$ physical hydraulic model testing.
\end{abstract}

Keywords: rubble-mound breakwater; toe reinforcement; single layer concrete armour units; physical model testing

\section{INTRODUCTION}

\section{Case Study - Colombo South Harbour}

Detailing of the toe reinforcement along the main breakwater for the Colombo South Harbour project is presented as a case study for a design solution driven by environmental and time impacts rather than by direct cost. During the project execution stage the breakwater toe design was optimized to best mitigate these impacts, and an alternative design solution using novel techniques was developed. Toe reinforcement designed as $8-12 \mathrm{t}$ rock armour was replaced with three additional rows of $8.5 \mathrm{~m}^{3}$ CORE-LOC ${ }^{\mathrm{TM}}$ single layer concrete armour units that are otherwise used as the main revetment primary armour.

\section{PROJECT BACKGROUND}

\section{Port expansion}

The Port of Colombo had established its position as the dominant transhipment port for the Indian sub-continent by the mid 1990s; its success was attributable to several natural advantages; its location on the East-West trunk routes between Asia Pacific, Europe and the US East Coast, and its proximity to the huge, rapidly expanding markets of the Indian sub-continent. The existing Port of Colombo is located in an artificial harbour formed by three breakwaters, constructed more than a century ago and is now fully developed.

At current levels of growth the existing port facilities in the Port of Colombo, Sri Lanka, are expected to reach capacity by end of 2013. This limit has been recognised by the Government of Sri Lanka, and in 2003 URS Scott Wilson Ltd. was appointed as Consultant to the Sri Lanka Ports Authority (SLPA) to prepare designs for the development of the outer Colombo South Harbour under joint funding by the Asian Development Bank and the Government of Sri Lanka.

The new Colombo South Harbour development project has been designed to accommodate main line container vessels in service for the foreseeable future, and includes two breakwaters with total length of over $6 \mathrm{~km}$ and dredging of a new two-way approach channel to enclose and protect a harbour basin sufficient for the development of three full container terminals - bringing the total to five container terminals in the Port of Colombo with a capacity of some 11.7 million TEU per annum.

Construction of the major USD 330 million harbour infrastructure works commenced in April 2008 and completed in 2012. The concession for the first container terminal is awarded, and is due to be operational in 2014. The new $5.2 \mathrm{~km}$ main breakwater (Figure 1) encloses a harbour basin of 285 hectares, for a total length $3.6 \mathrm{~km}$ of deep draft quay for vessels up to $400 \mathrm{~m}$ length overall and up to $16 \mathrm{~m}$ draft. The harbour layout and breakwater are designed to provide protection from the South West monsoon, which can bring severe storm conditions to the area.

\footnotetext{
${ }^{1}$ URS Infrastructure \& Environment UK Ltd. martin.young@urs.com

${ }^{2}$ URS Infrastructure \& Environment UK Ltd. john@johnhayman-joyce.demon.co.uk

${ }^{3}$ Hyundai Engineering \& Construction Co. Ltd. seokhyeon.kim@hdec.co.kr
} 


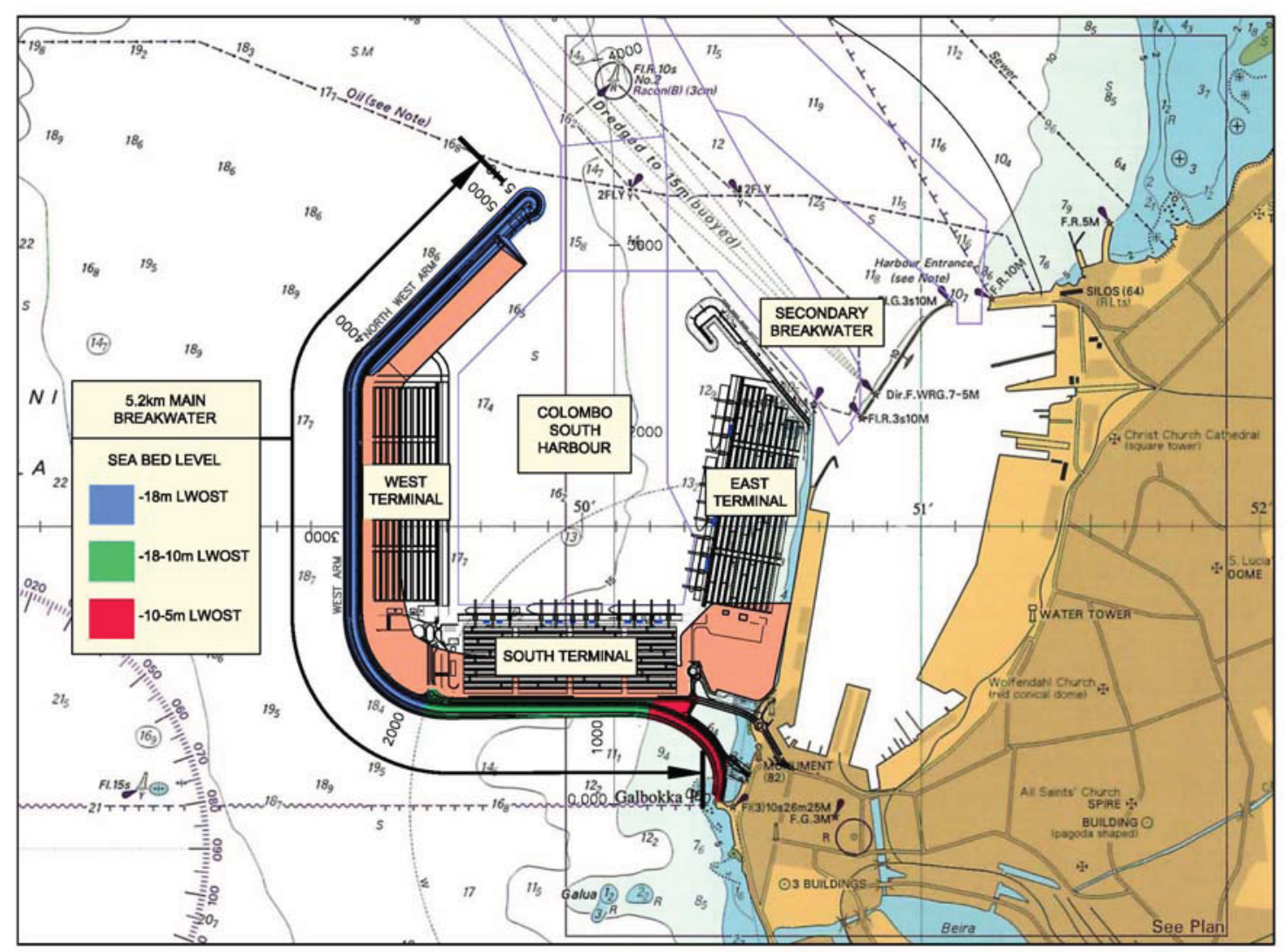

Figure 1: Colombo South Harbour showing the main breakwater

\section{Design stage environmental mitigation}

Supply of rock armour in large volumes is not an easy task in Sri Lanka due to the strict environmental controls on quarry operations, and the allocation of suitable haul routes. Sri Lankan quarries normally produce road metal and concrete aggregates, and very few are equipped with the heavy track drill equipment required for preferential rock armour production. A study of potential sources of construction material for the breakwater construction and the means of transport to the site was conducted as part of the EIA. It was deemed necessary for the majority of the material to be brought to the site using sea transport.

Whilst it was in the overall interests of the project to minimise the demand for quarry products, there was particular interest placed during the design to reduce the demand for heavy armour rock gradings. Yield of heavy armour from normal blasting can be low and can result in significant secondary production of smaller quarry run material. The concept design for the main breakwater sought to move away from a conventional rubble mound (behind which reclamation is placed), and instead focused on development of a typical cross section that is more a substantial reclamation protected by a revetment on the seaward face. Two main choices were made for the design of the main breakwater to best mitigate the broader environmental impact of the project:

- maximum use of dredged sand in the breakwater core

- use of single layer concrete armour units as the primary armour.

The outer harbour is in deep water, however in order to provide for next generation container vessels a new two-way approach channel dredged to $-20 \mathrm{~m}$ LWOST was necessary. The volume of reclamation in the main breakwater was balanced with the dredging required for the approach channel. Short sailing times in the dredging cycle improve productivity and also mitigate construction stage impacts. Subsequent reclamation for the staged terminal development will come initially from the harbour basin. 


\section{MAIN BREAKWATER REVETMENT DESIGN}

\section{Design wave climate}

The seasonal effect on wave climate at Colombo due to the southwest monsoon is well known, bringing strong winds and increased swell from May to September. During construction of the original breakwater for the existing Port of Colombo the Resident Engineer reported in the Proceedings of the Institution of Civil Engineers (Kyle, 1886) that "In April 1878, an unusually heavy southwest monsoon set in, and swept away a 14-ton block from eth second upper course of the scar end.."

Indian Ocean tropical cyclones rarely form to the Southwest of Colombo, however when they do they can bring extreme wave conditions to Colombo. Two such storms occurred during the period 1950-75: one moved to the West (away from Colombo), but the other headed Northeast and passed approximately 50 nautical miles Northwest of Colombo, producing nearly 50 knot winds at Colombo.

Sea waves occur all year round in the vicinity of Colombo. High sea waves occur during the southwest monsoon due to intense local storms. During the inter-monsoon periods, depression weather systems can lead to high sea waves from directions between Southwest and Northwest. As a consequence of these mechanisms, the sea state may consist of sea and swell with similar directions or during the northeast monsoon the sea and swell may have quite different directions (Figure 2). In addition to these permanent features, cyclones occur infrequently but may generate some of the highest waves. Hence sea states are complex.
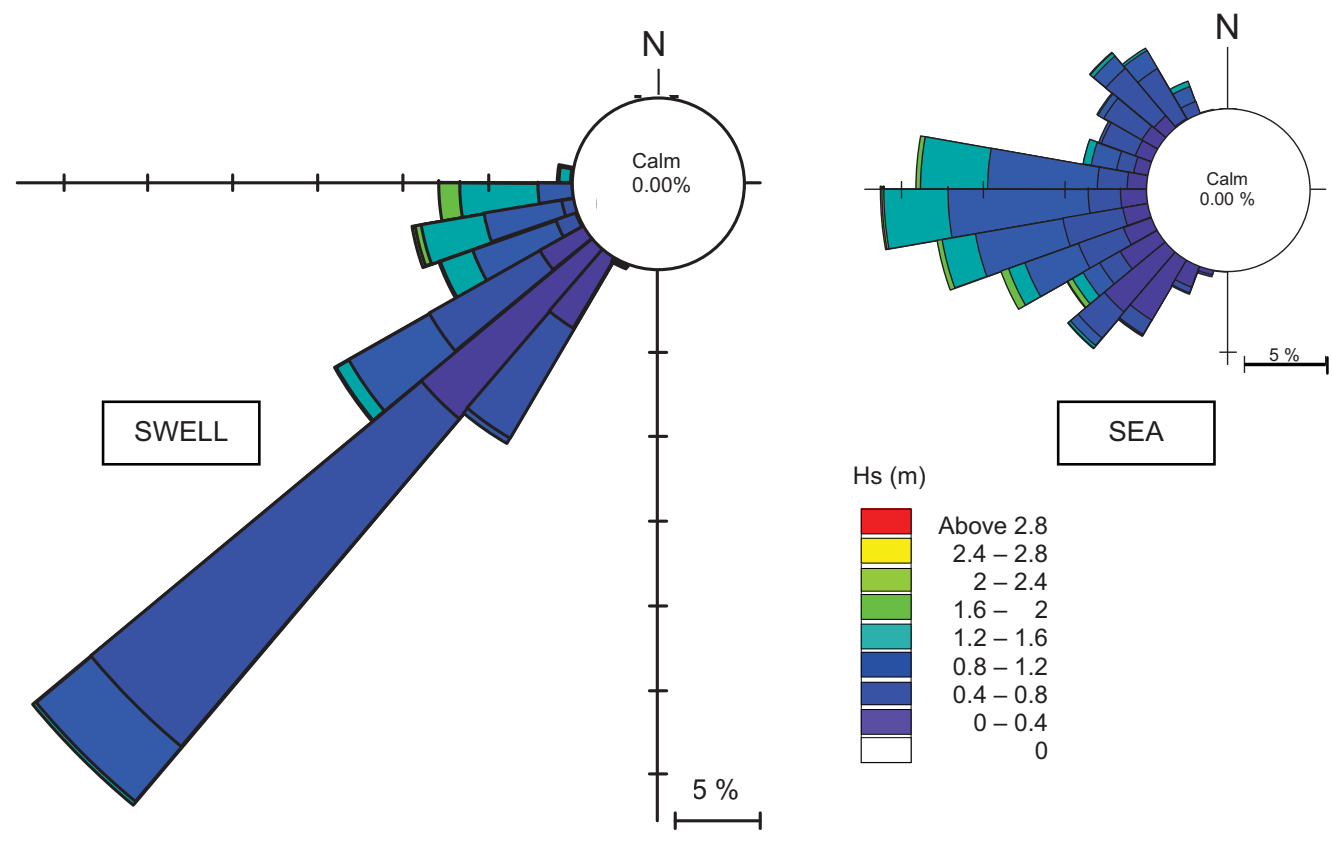

Hs (m)

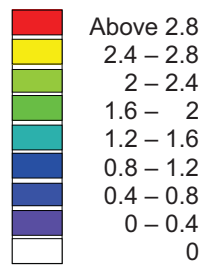

Figure 2: Annual Swell and Sea Wave Roses

Measured wave data at Colombo are scarce. Directional wave measurement collected at $-16 \mathrm{~m}$ LWOST using S4DW electromagnetic current meter was initiated during the project feasibility stage and continued through the design (and subsequently during construction). During detailed design a relatively short data set (taken over 6 years) was available for extreme value analysis (Table 1).

\begin{tabular}{|c|c|c|c|}
\hline \multicolumn{4}{|c|}{$\begin{array}{c}\text { Table 1: Extreme Wave Criteria at Breakwater, All } \\
\text { Directions, Overall Wave Height }\end{array}$} \\
\hline $\begin{array}{c}\text { Return Period } \\
(\mathrm{yrs})\end{array}$ & $\mathrm{H}_{\mathrm{s}}(\mathrm{m})$ & $\mathrm{T}_{\mathrm{p}}(\mathrm{s})$ & $\mathrm{T}_{\mathrm{z}}(\mathrm{s})$ \\
\hline $200+20 \%$ & 7.7 & $14-17$ & 11 \\
\hline 200 & 6.4 & $13-16$ & 10 \\
\hline 100 & 5.8 & $13-16$ & 10 \\
\hline 50 & 5.3 & $12-15$ & 10 \\
\hline 10 & 4.2 & $11-14$ & 9 \\
\hline 2 & 3.7 & $11-14$ & 8 \\
\hline 1 & 2.7 & $9-12$ & 7 \\
\hline 0.1 & 2.1 & $7-10$ & 6 \\
\hline
\end{tabular}


The design standard for the breakwater is set at 1 in 200 years. This is consistent with UK practice as set out in BS6349, which advises that the return period for design should be set so as to achieve an acceptable encounter probability during the whole design life of the structure. A design life of 60 years and a design standard of 1 in 200 years gives an encounter probability of $26 \%$, which is considered appropriate for Sri Lanka where the difficulties of undertaking significant repair works would be great and the consequences to the economy of loss of the major port would be substantial.

\section{Primary Armour Selection}

The main breakwater is constructed in relatively deep water (seabed -18mLWOST) and the slope of the seaward facing revetment has a significant impact on the rock volume required in the cross section. Preliminary sizing indicated primary rock armour with an average weight well in excess of practical limits for Sri Lankan quarries would be required, and therefore single layer armour units were considered. These are generally tested for use on steeper slopes than rock and provide a cost-effective solution that significantly mitigates the environmental impact associated with rock armour production and transport. During the design stage two single layer units were available in the market with successful history of use. CORE-LOC ${ }^{\text {TM }}$ units use slightly less concrete per square metre covered than the Accropode units, and were therefore adopted as primary armour for the main breakwater.

Based on a preliminary design wave height $\mathrm{Hs} 7.2 \mathrm{~m}$, a unit size $\left(8.5 \mathrm{~m}^{3}\right)$ was selected from the CORE-LOCTM design tables for a limiting wave height of $7.5 \mathrm{~m}$. As the design progressed and wave analysis was completed the design wave height $\mathrm{Hs} 6.4 \mathrm{~m}$ was set. The wave data set is over a relatively short time period (6 years) and an increasingly higher level of uncertainty was assumed for return periods more than 50 years, and therefore a conservative approach was taken and unit size was left unadjusted. The CORE-LOC ${ }^{\text {TM }}$ design guide recommends that physical modeling of the structure should be undertaken at both the nominal design height and at a wave height increased by $20 \%$. This is to ensure that the structure will not catastrophically fail when subjected to a wave event only marginally greater than the nominal design. In this case the breakwater was tested at $\mathrm{Hs} 7.7 \mathrm{~m}(6.4 \mathrm{~m}$ plus $20 \%$ ) and survived with no damage, which is equivalent to the 1,000 year return period wave condition.

\section{Development of the Revetment Toe}

The proposed main breakwater cross section was tested and developed in a series of 2D physical hydraulic model tests at 1:49 scale in a $0.8 \mathrm{~m} \times 1.0 \mathrm{~m}$ flume with a length of $30 \mathrm{~m}$ with wave return periods up to the design wave and overload condition. Tests at high and low water were performed.

An initial cross section with a 3:2 slope and CORE-LOC ${ }^{\text {TM }}$ primary armour down to $-7.5 \mathrm{~m}$ LWOST was tested to see if reduced wave action below this level allowed smaller rock armour to be used on the lower part of the slope. Rock armour in the toe berm with top level at -11.3m LWOST was sized according to Van der Meer, d'Angremond and Gerding (1995) at 3-6t. This cross section proved unstable in preliminary flume tests due to inadequate support at the toe of the CORE-LOC ${ }^{\text {TM }}$ units. Accepted practice (without further detailed analysis) limits the number of rows of single layer units used on a slope in order to control in-plane stresses to acceptable levels and avoid structural overload of the units. The cross section was amended by raising the toe berm up to the toe of the CORE-LOC units (-7.5m LWOST), without increasing the number of rows in the primary armour (Figure 3 ).

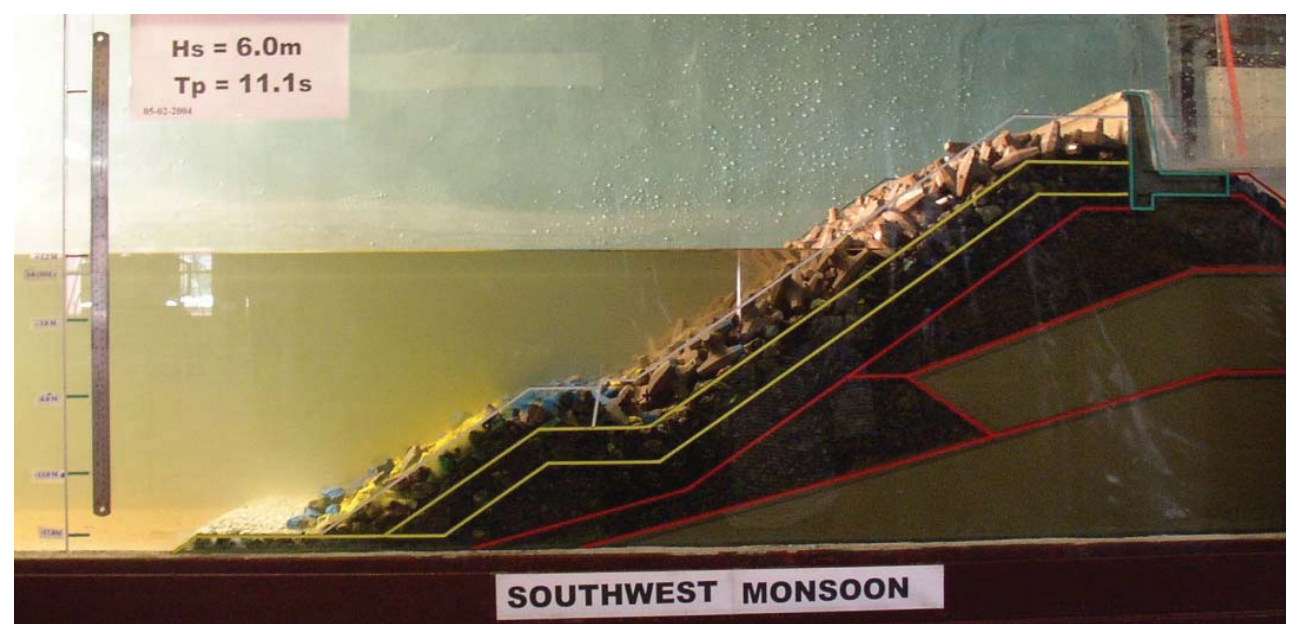


Figure 3: Toe Berm at -7.5m LWOST, Revetment slope 3:2

In this arrangement the first row of CORE-LOCTM units is placed in a cannon arrangement on the horizontal toe so that each unit in this row has stable three point contact with the rock underlayer. Rock armour is placed in front as reinforcement. The rock size used for reinforcement was calculated as if it was used in a toe berm as 5-8t. Flume testing showed that the CORE-LOC ${ }^{\text {TM }}$ primary armour was stable on this cross section - however damage on the toe reinforcement was severe.

It was evident that the down rush with extreme waves was reaching the berm, and it was apparent that the berm needed to be lower. The revetment slope was steepened to $4: 3$, allowing the toe berm to be deepened to $-8.7 \mathrm{~m}$ LWOST whilst maintaining eighteen rows of CORE-LOC ${ }^{\text {TM }}$ units in the slope. Rock size used for the toe reinforcement was initially re-sized at 6-10t based on earlier test observations, however flume test results showed unacceptable 12\% damage (Figure 4 ). The CORELOC ${ }^{\text {TM }}$ primary armour remained stable on the steeper slope. In further tests based on this cross section it was established that using rock size 10-14t in the toe berm gave an acceptable solution with only $3 \%$ damage.

By this stage in the design the results of ground investigation were available. For geotechnical stability of the proposed breakwater cross section it was found that the toe apron needed to be thickened and extended seawards to provide sufficient resistance (Figure 4). The apron influences wave form at the breakwater and repeat flume tests were carried out to validate the hydraulic design. During these tests it was found that the rock armour size in the toe berm, with top level at $-8.3 \mathrm{~m}$ LWOST, could be optimised at 8-12t.

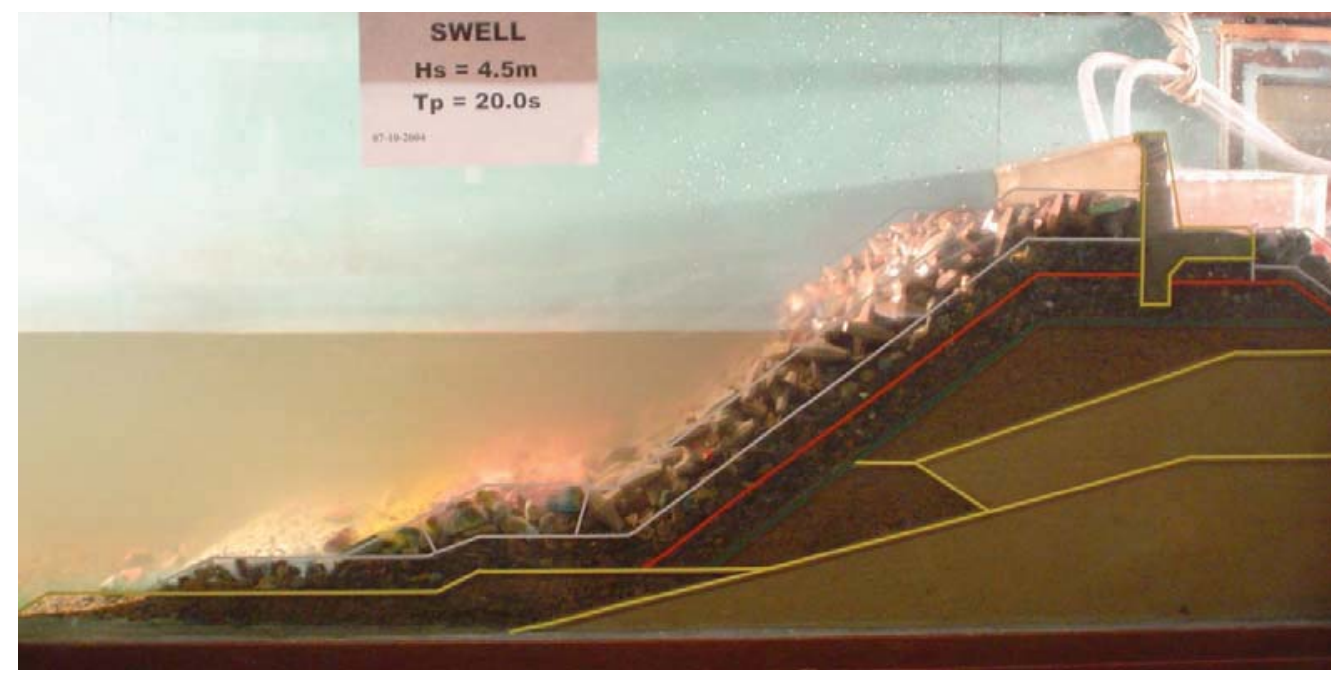

Figure 4: Toe Berm at -8.3m LWOST, Revetment slope 4:3, Toe Apron thickened for geotechnical stability

As a general note it was seen that the size required for rock reinforcement in the toe berm was larger than calculated according to Van der Meer, d'Angremond and Gerding (1995), and this may be due to the position of the berm slightly above the toe apron. More recent research by Baart et al (2011) on the stability of rock used in toe armour presents updated analytical techniques. When applied to the tested cross section the rock size calculated according to the later method is in closer agreement with the optimised size established by 2D physical model testing.

\section{CONSTRUCTION STAGE}

\section{Toe surcharge and toe rationalization}

Ground conditions under the southwestern part of the main breakwater were poor, and needed treatment before construction of the breakwater. Rather than dredge and replace, the design made use of sand arising from the channel dredging and placed it as a temporary underwater surcharge (up to $7 \mathrm{~m} \mathrm{LWOST}$ ) that remained in place for a minimum period of four months to allow for consolidation to occur. Thereafter the sand was re-handled and placed into the permanent reclamation works for the breakwater. In the original design the breakwater apron was a constant thickness of rock armour and quarry run placed on to existing seabed level, and was joined to the toe berm by a rock armour slope of varying length. 
However, the consequence of placing surcharge on the revetment toe design was that the precommencement seabed levels were lost. When reviewed with the Contractor it was decided that it was easier to dredge the sand down to a constant level and simplify the geometry between the apron and toe berm - so optimizing the use quarry run in this part of the structure (Figure 5). This toe rationalization saved on construction time by being simpler, and saved on quarry materials used in the breakwater. Easier construction improves the tolerance on finished work and delivers a higher end quality.

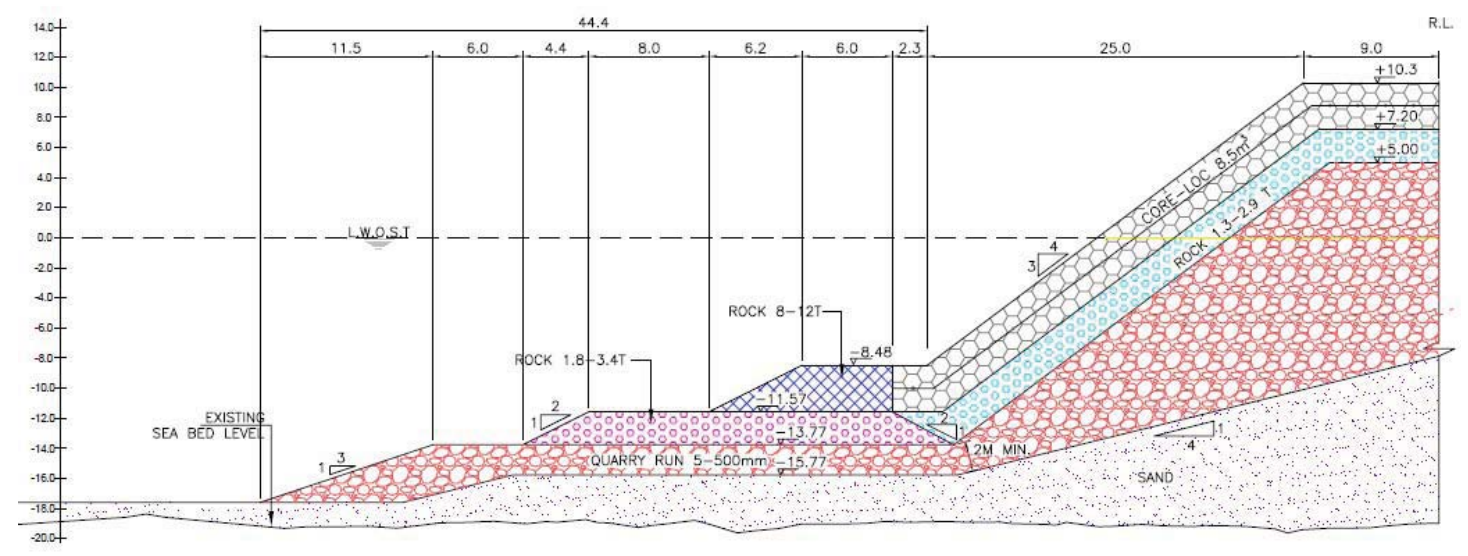

Figure 5: Toe Rationalisation

\section{Alternative toe reinforcement}

The volume of $8-12 \mathrm{t}$ rock required for toe reinforcement was only $0.2 \mathrm{Mm}^{3}$, which is approximately $5 \%$ of the total estimated volume $\left(3.8 \mathrm{Mm}^{3}\right)$ of rock and quarry products required for the breakwater construction. In most situations achieving sufficient yield at this size from the overall quarry production would be manageable, however it became apparent soon after the Contractor started stockpiling rock armour that actual yield being achieved would fall short of requirements. Discussion was opened on possible alternative solutions. Work methods for production and placing CORE-LOC'M units were well established and proven on Site, and the option of using additional CORE-LOC ${ }^{\mathrm{TM}}$ units as alternative toe reinforcement was a logical progression to overcome a supply issue that was becoming a constraint on progress of the Works.

Whilst other alternatives, such as cubes or Tetrapods, could have been considered in more detail, the lead time required to bring these options on stream was considered an issue. More importantly, review of the design stage development of the toe berm geometry clearly demonstrated the sensitivity in the hydraulic stability of the toe reinforcement to level change in the toe berm. Potential use of a double layer concrete armour unit, such as cubes or Tetrapods would likely lead to an increase overall layer thickness - with knock-on implications for the toe apron geometry. Considering that construction was ongoing, other alternatives were dropped from further evaluation by inspection.

As conventional slope armour there was no question that the $8.5 \mathrm{~m}^{3}$ CORE-LOCTM units would have better hydraulic stability than the 8-12t rock placed in double layer, however placing the units on the flat rock apron was untested and needed technical evaluation before the option could proceed. Two areas were investigated:

- Placing pattern and packing density - by prototype scale dry trial

- Hydraulic stability - by repeat 1:48 scale 2D physical hydraulic model testing

In practical terms placing CORE-LOCTM units requires significantly less crane lifts for the same square metre coverage. Saving crane time on the placing operation gives some mitigation on the increased material costs.

The original design width of the toe berm was $6.0 \mathrm{~m}$, which for $8-12 \mathrm{t}$ rock equates to approximately four stones wide. This is in agreement with the guideline given by Van der Meer, d'Angremond and Gerding (1995) that a standard size toe is 3-5 stones wide. This width can also be compared to the minimum width recommended in the Rock Manual of 3.3 Dn50 - or 5.1m. The alternative being considered (Figure 6) needed to demonstrate equivalence with the original design, and therefore the number of rows of CORE-LOCTM units used as toe reinforcement was selected to match the original width. 


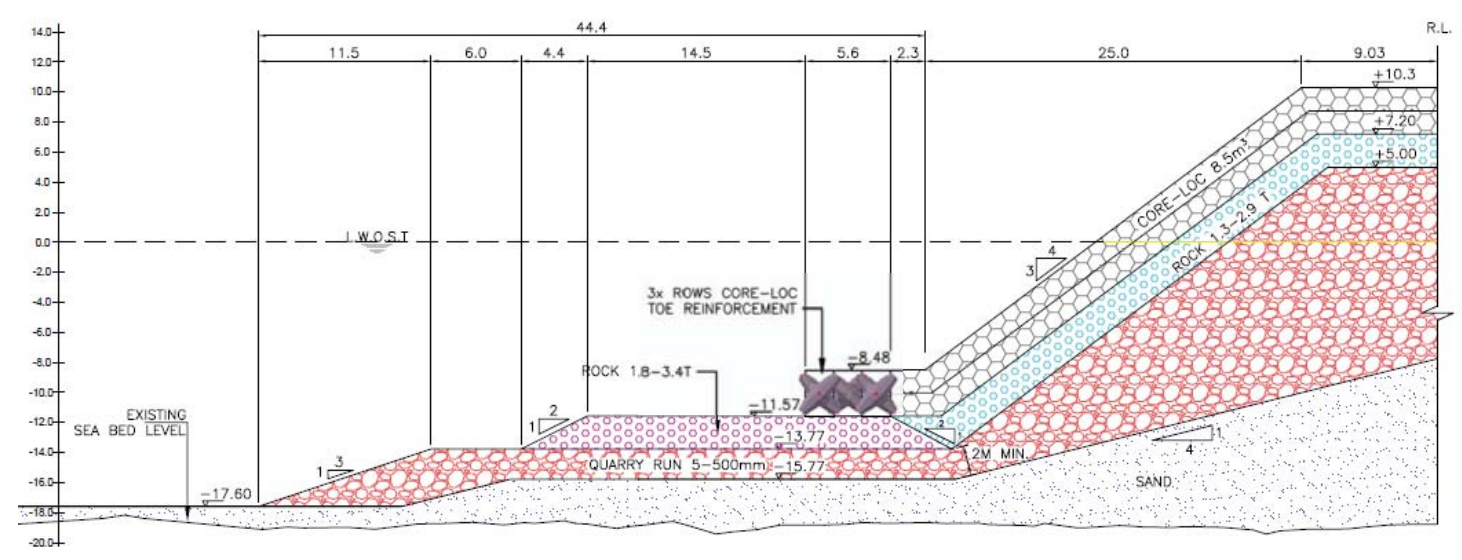

Figure 6: Alternative Toe Reinforcement

\section{Prototype scale dry trial}

Proposed use of CORE-LOCTM units placed underwater on the flat was discussed with Concrete Layer Innovations (CLI), who noted that experience for this type of use was limited. The only similar case was placement as scour protection over a submerged tunnel. CLI advised that:

- Cannon placement, giving stable three point contact with the rock underlayer should be preferred.

- Placement of the toe row and first few slope rows of CORE-LOCTM units in the primary armour must be completed first before the toe reinforcement.

It is well established from project experience that care taken with preparation for and placement of the toe row to good line and level makes easy work of placing the balance part of the revetment, and the CLI requirement to place this toe row unobstructed is self evident. As the toe reinforcement units should also be placed in contact with each other, it was clear that toe reinforcement units would have to be placed in rows in sequence going seawards. It was decided that a prototype scale dry trial should be carried out, following the above principles in order to test placing patterns and verify that the necessary interlock and contact could be reasonably achieved. Presuming that the dry trial demonstrated that a workable and practical solution was possible, then survey and results from the dry trial would be used by CLI to prepare placing drawings giving individual positions for the toe reinforcement units.

The dry trial was set up on a prepared quarry run stockpile. The slope was trimmed and rock underlayer was placed over sufficient toe apron area and initial part of the slope so that CORE-LOC ${ }^{\text {TM }}$ units could be placed as both primary armour and toe reinforcement. The same $250 \mathrm{t}$ crawler crane, site engineers, operators and labour that were already experience in placing the primary armour units were utilised for the dry trial. For this project positioning of the CORE-LOCTM units underwater is made with the POSIBLOC ${ }^{\text {TM }}$ system, which gives in-cab real time visualisation of the unit being placed and the surrounding units so that the site engineer can assess and control position and interlock during placement. This was also used for the dry trial, and the crane operators cab windows were blacked out to simulate underwater placement.

The dry trial comprised placing a total of twenty units in rows (Table 2). Placement of the first toe row of CORE-LOCTM units is alternating cannon fashion, with units arranged with their axis at approximately 45 degrees either side of perpendicular to the breakwater setting out line.

\begin{tabular}{|c|c|c|c|}
\hline \multicolumn{5}{|c|}{ Table 2: Composition of Dry Trial } \\
\hline $\begin{array}{c}\text { Placing } \\
\text { sequence }\end{array}$ & Trial name & Designation & No. of units \\
\hline 1 & Row 01 & Primary armour toe $\left(1^{\text {st }}\right)$ row & 6 \\
\hline 2 & - & Primary armour $2^{\text {nd }}$ row $($ slope $)$ & 5 \\
\hline 3 & Row 02 & Toe reinforcement $1^{\text {st }}$ row & 5 \\
\hline 4 & Row 03 & Toe reinforcement $2^{\text {nd }}$ row & 4 \\
\hline
\end{tabular}

An acceptable pattern placement was worked out fairly rapidly and it was considered to conclude the dry trial after placing two rows of toe reinforcement, as illustrated on the following photographs taken during the dry trial (Figures 7-11). 


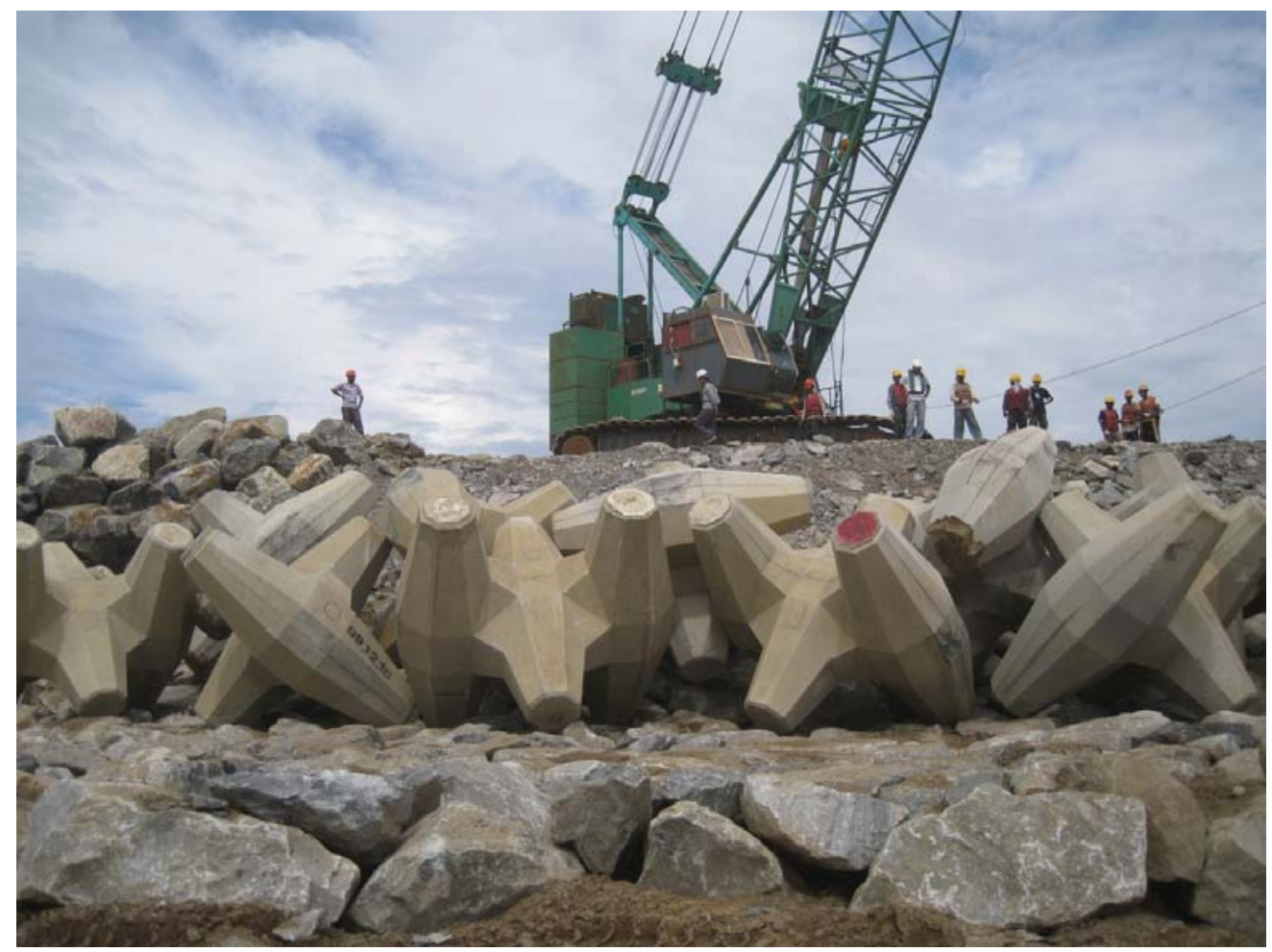

Figure 7: Start of Dry Trial - view of primary armour toe row (Row 01)

Note alternating cannon placement.

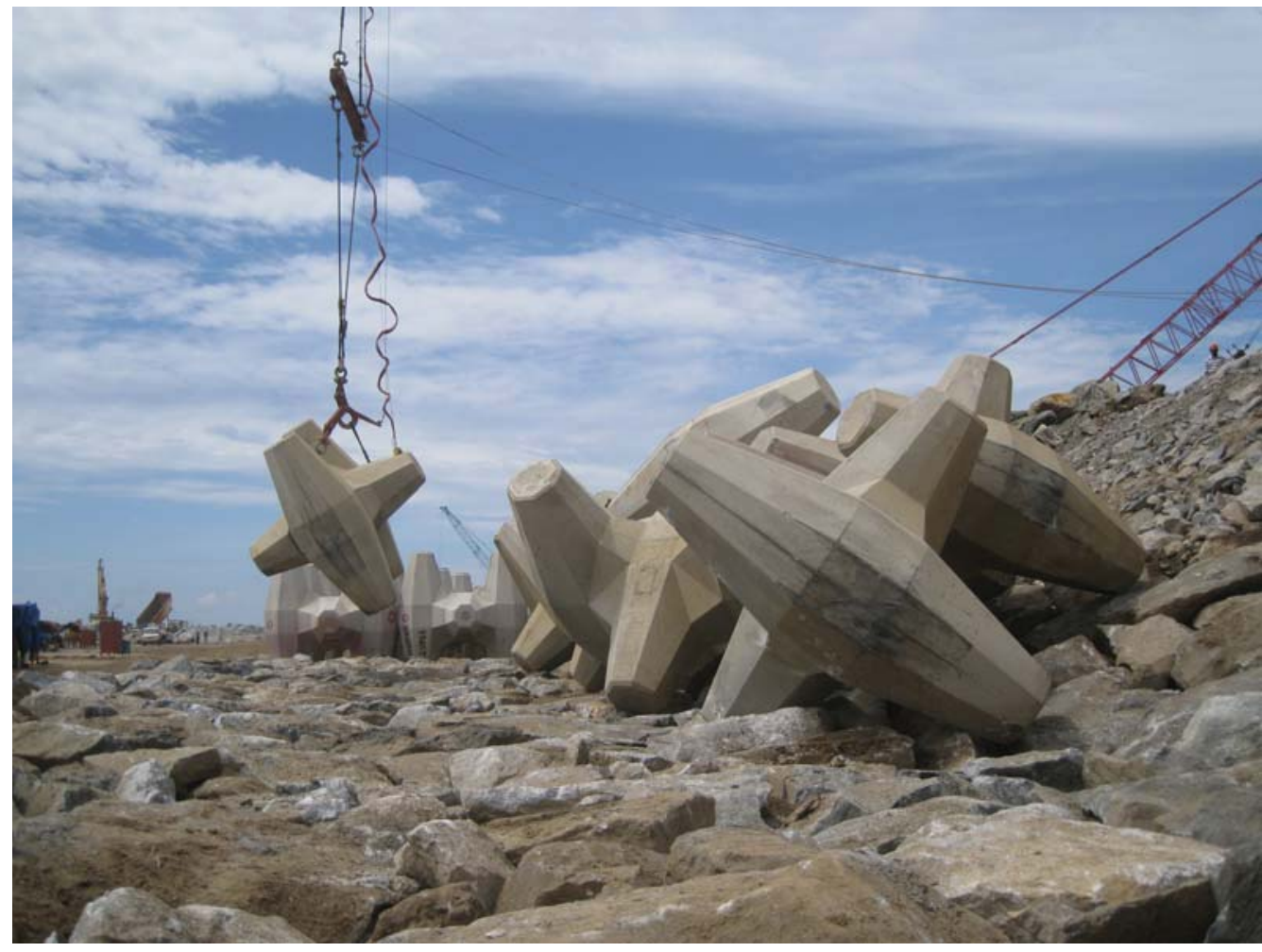

Figure 8: Toe Reinforcement - Placement of first row (Dry Trial Row 02)

Note bib sensor attached to suspended unit recording orientation for POSIBLOCTM. 


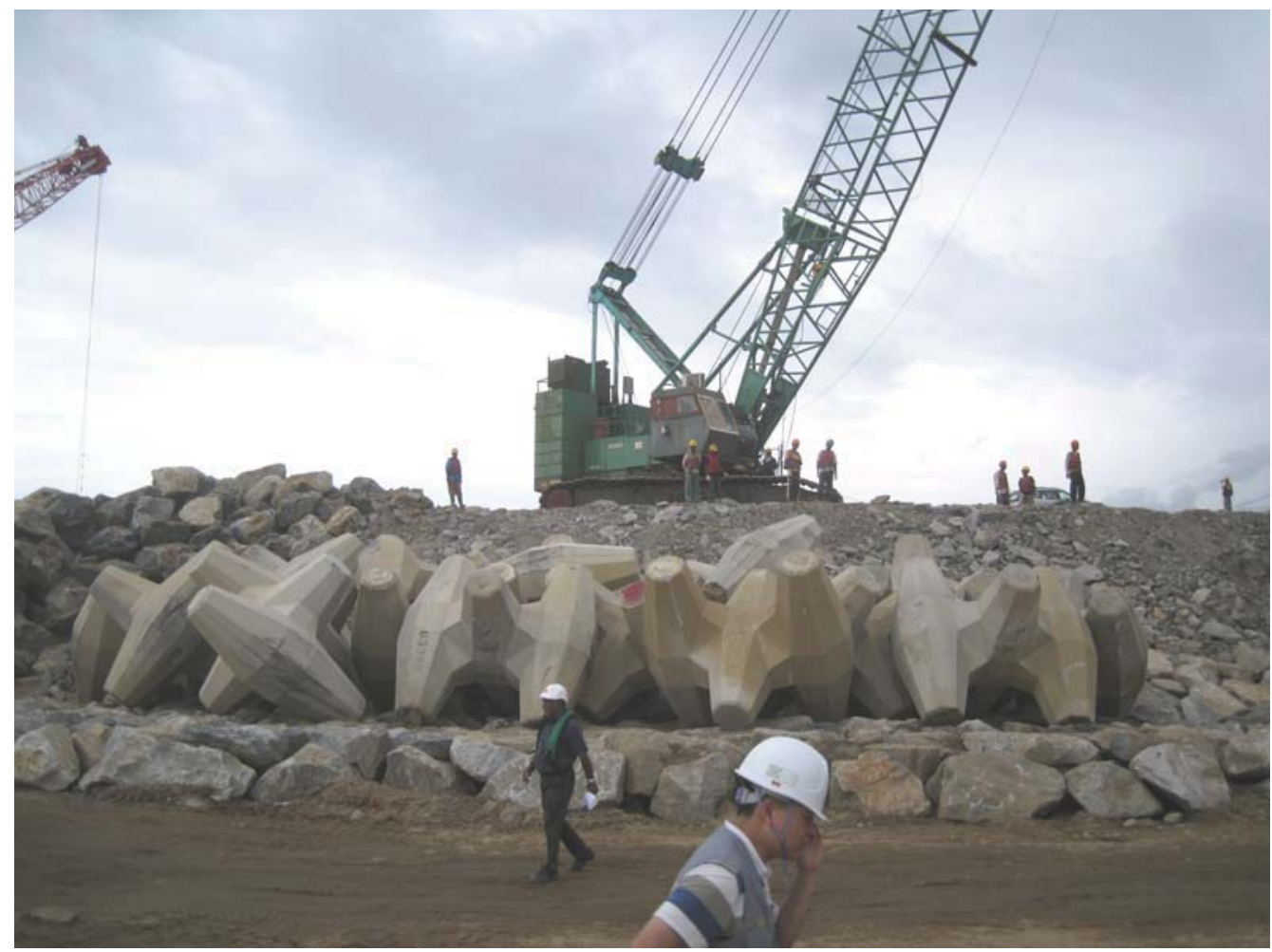

Figure 9: Toe Reinforcement - first row complete (Dry Trial Row 02)

Note "alternate opposing cannon" pattern placement.

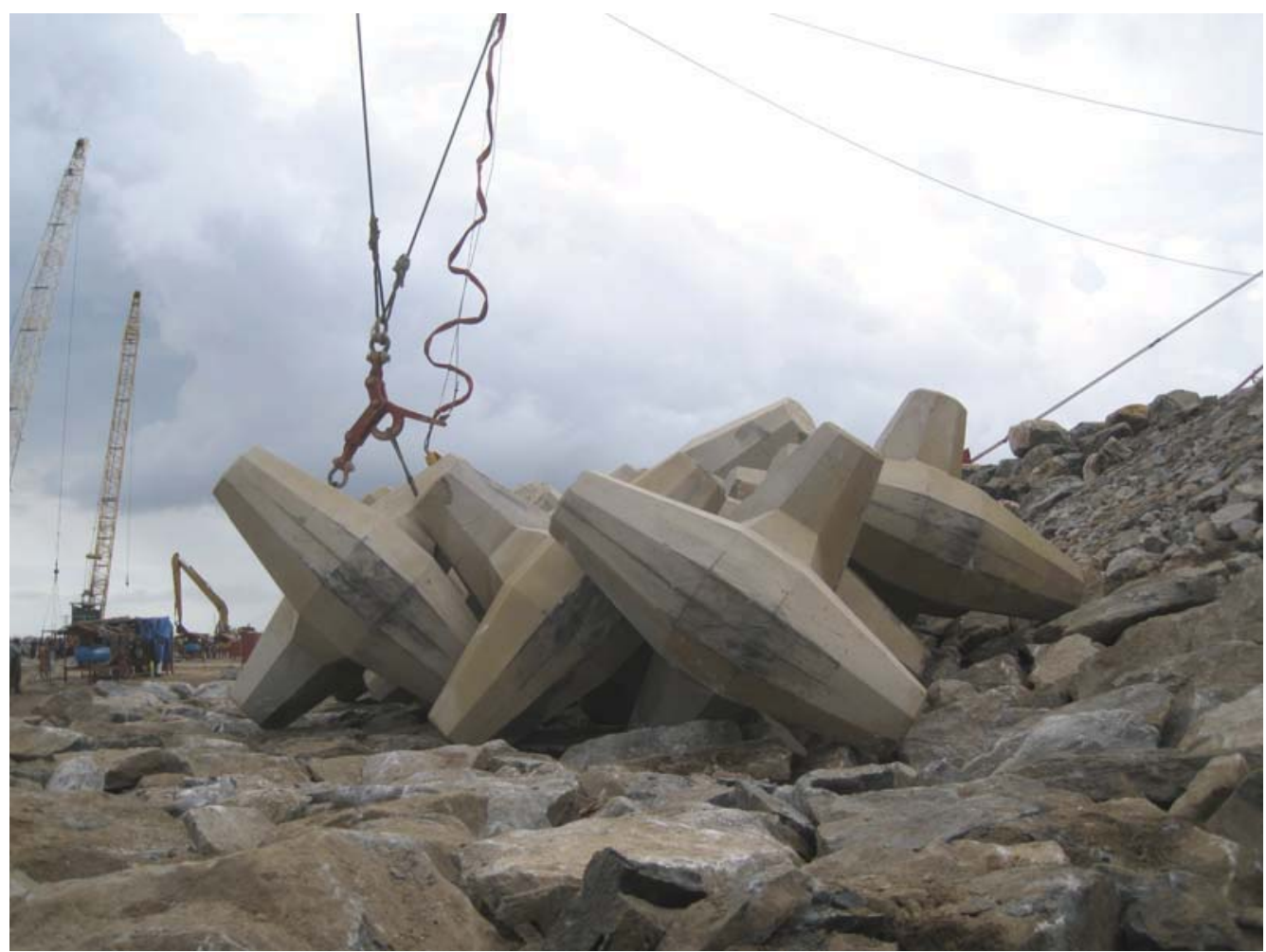

Figure 10: Toe Reinforcement - Placement of second row (Dry Trial Row 03)

Note interlock achieved without need to swing unit. 


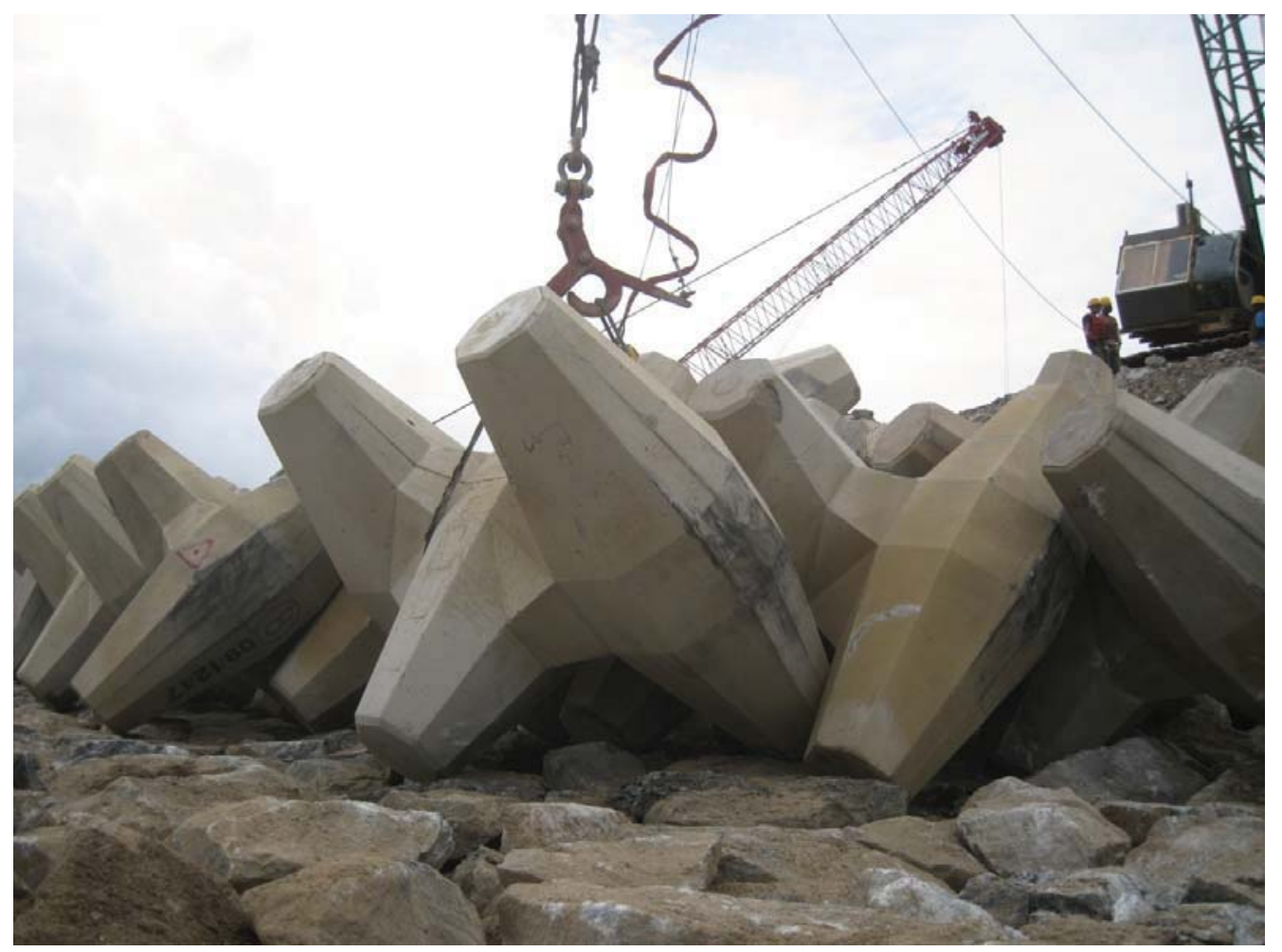

Figure 11: Toe Reinforcement - second row complete (Dry Trial Row 03)

Note packing arrangement using alternate opposing cannon placement.

Normal unit placement follows a lozenge pattern (centre positions) and required packing density is controlled by specifying spacing of units along each row $\left(D_{H}\right)$, and spacing between rows $\left(D_{V}\right)$. These are expressed as ratios of "C", being the single dimension given for each size of CORE-LOC" For the Colombo South Harbour project, which uses $8.5 \mathrm{~m}^{3}$ units, the dimension " $\mathrm{C}$ " is $3.36 \mathrm{~m}$. Unit spacings were measured from the dry trial so that actual $\mathrm{D}_{\mathrm{H}}$ and $\mathrm{D}_{\mathrm{V}}$ could be assessed (Figure 12, Table 3, Table 4).

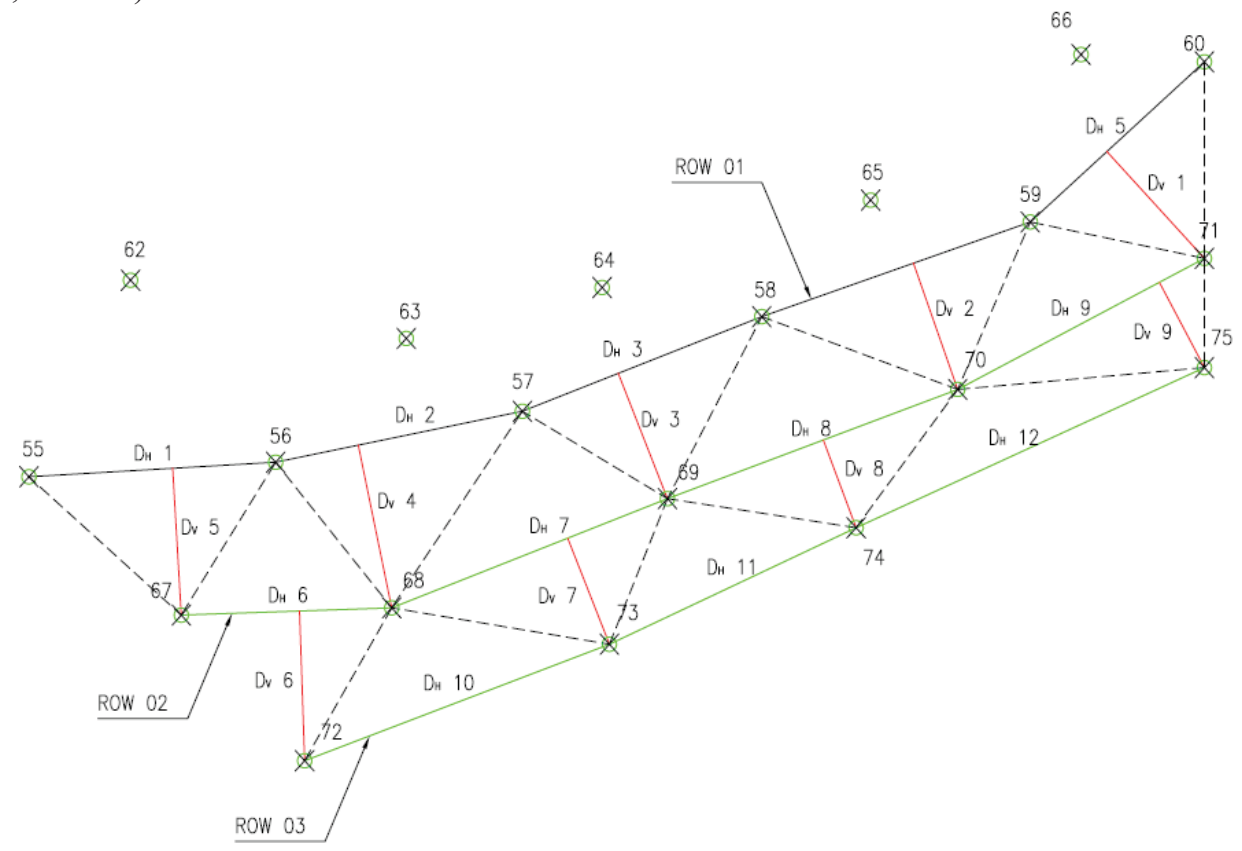

Figure 12: Dry Trial - Position Analysis 


\begin{tabular}{|c|c|c|c|c|c|}
\hline \multicolumn{6}{|c|}{ Table 3: Toe Reinforcement - Horizontal Unit Spacing } \\
\hline Trial Row & No. & Length $(m)$ & $\begin{array}{l}\text { Row Average } \\
(\mathrm{m})\end{array}$ & C & $\begin{array}{c}\text { Row } \\
\text { Average C }\end{array}$ \\
\hline \multirow{5}{*}{01} & $\mathrm{D}_{\mathrm{H}} 1$ & 3.41 & \multirow{5}{*}{3.77} & 1.01 & \multirow{5}{*}{1.05} \\
\hline & $\mathrm{D}_{\mathrm{H}} 2$ & 3.47 & & 1.03 & \\
\hline & $D_{H} 3$ & 3.55 & & 1.06 & \\
\hline & $\mathrm{D}_{\mathrm{H}} 4$ & 3.92 & & 1.17 & \\
\hline & $\mathrm{D}_{\text {H }} 5$ & 3.26 & & 0.97 & \\
\hline \multirow{4}{*}{02} & $D_{H} 6$ & 2.90 & \multirow{4}{*}{3.77} & 0.86 & \multirow{4}{*}{1.12} \\
\hline & $D_{H} 7$ & 4.08 & & 1.21 & \\
\hline & $\mathrm{D}_{\mathrm{H}} 1$ & 4.27 & & 1.27 & \\
\hline & $D_{H} 9$ & 3.84 & & 1.14 & \\
\hline \multirow{3}{*}{03} & $D_{H} 10$ & 4.49 & \multirow{3}{*}{4.51} & 1.34 & \multirow{3}{*}{1.34} \\
\hline & $\mathrm{D}_{\mathrm{H}} 11$ & 3.75 & & 1.12 & \\
\hline & $D_{H} 12$ & 5.28 & & 1.57 & \\
\hline Trial Average & $D_{H}$ & 3.85 & & 1.15 & \\
\hline Primary Armour & $D_{H}$ & 3.72 & & 1.11 & \\
\hline
\end{tabular}

\begin{tabular}{|c|c|c|c|c|c|}
\hline Section & No. & Length $(\mathrm{m})$ & $\begin{array}{c}\text { Section } \\
\text { Average }(\mathrm{m})\end{array}$ & C & $\begin{array}{c}\text { Section } \\
\text { Average C }\end{array}$ \\
\hline \multirow{5}{*}{ 01 02 } & $D_{\vee} 1$ & 1.99 & \multirow{5}{*}{1.99} & 0.59 & \multirow{5}{*}{0.59} \\
\hline & $D_{\vee} 2$ & 1.83 & & 0.54 & \\
\hline & $D_{\vee} 3$ & 1.84 & & 0.55 & \\
\hline & $D_{\vee} 4$ & 2.28 & & 0.68 & \\
\hline & $D_{\vee} 5$ & 2.02 & & 0.60 & \\
\hline \multirow{4}{*}{$02 \sim 03$} & $D_{\vee} 6$ & 2.05 & \multirow{4}{*}{1.55} & 0.61 & \multirow{4}{*}{0.46} \\
\hline & $D_{\vee} 7$ & 1.56 & & 0.46 & \\
\hline & $D_{\vee} 8$ & 1.28 & & 0.38 & \\
\hline & $D_{\vee} 9$ & 1.32 & & 0.39 & \\
\hline Trial Average & $\mathrm{D}_{\mathrm{v}}$ & 1.80 & & 0.53 & \\
\hline Primary Armour & $D_{v}$ & 1.84 & & 0.55 & \\
\hline
\end{tabular}

\section{D hydraulic physical model testing}

After completing the dry trial, the hydraulic stability of the alternative toe reinforcement was checked and validated in a series of 1:48 scale physical hydraulic model tests. These were undertaken in the same flume and using the same 6 hour storm design wave conditions used for testing the original design. The test series examined the influence of number of rows of toe reinforcement at high and low water levels, and at two bed levels (Table 5) under extreme wave loading conditions. Water depth towards the main breakwater roundhead is slightly reduced and the foreshore slope is marginally steeper.

\begin{tabular}{|c|c|c|c|c|c|c|}
\hline \multicolumn{7}{|c|}{ Table 5: Repeat Flume Test Series } \\
\hline $\begin{array}{c}\text { Toe } \\
\text { Reinforcement }\end{array}$ & $\begin{array}{l}\text { Test } \\
\text { No. }\end{array}$ & $\begin{array}{c}\text { Seabed level } \\
\text { (m LWOST) }\end{array}$ & $\begin{array}{c}\text { Return } \\
\text { Period (yr) } \\
\end{array}$ & $\mathrm{Hs}(\mathrm{m})$ & $\mathrm{Tp}(\mathrm{s})$ & $\begin{array}{l}\text { Water level } \\
\text { (m LWOST) }\end{array}$ \\
\hline \multirow{2}{*}{2 rows } & T5 & \multirow{3}{*}{-18.5} & 100 & 5.8 & 16 & 0.0 \\
\hline & T6 & & $200+20 \%$ & 7.7 & 14 & 0.0 \\
\hline 4 rows & T7 & & $200+20 \%$ & 7.7 & 14 & 0.0 \\
\hline \multirow{2}{*}{3 rows } & T8 & \multirow{2}{*}{-16.5} & $200+20 \%$ & 7.7 & 14 & 1.2 \\
\hline & T9 & & $200+20 \%$ & 7.7 & 14 & 0.0 \\
\hline
\end{tabular}

Prior to testing it was unknown whether the abrupt change of profile at the outermost toe reinforcement row would be stable. Often the outer edge of rock aprons will either be flattened in the design, or flattened with wave loading. However during testing it was seen that smaller quarry run material that was dislodged from the seaward edge of the apron as its profile adjusted tended to move back into and rest against the outermost CORE-LOC ${ }^{\mathrm{TM}}$ units in the toe reinforcement - indicating that this detail is stable (Figure 13).

All tests showed that the alternative toe reinforcement design using CORE-LOC'M single layer concrete armour units was stable under design wave conditions, and it was accepted for use along the main breakwater. 


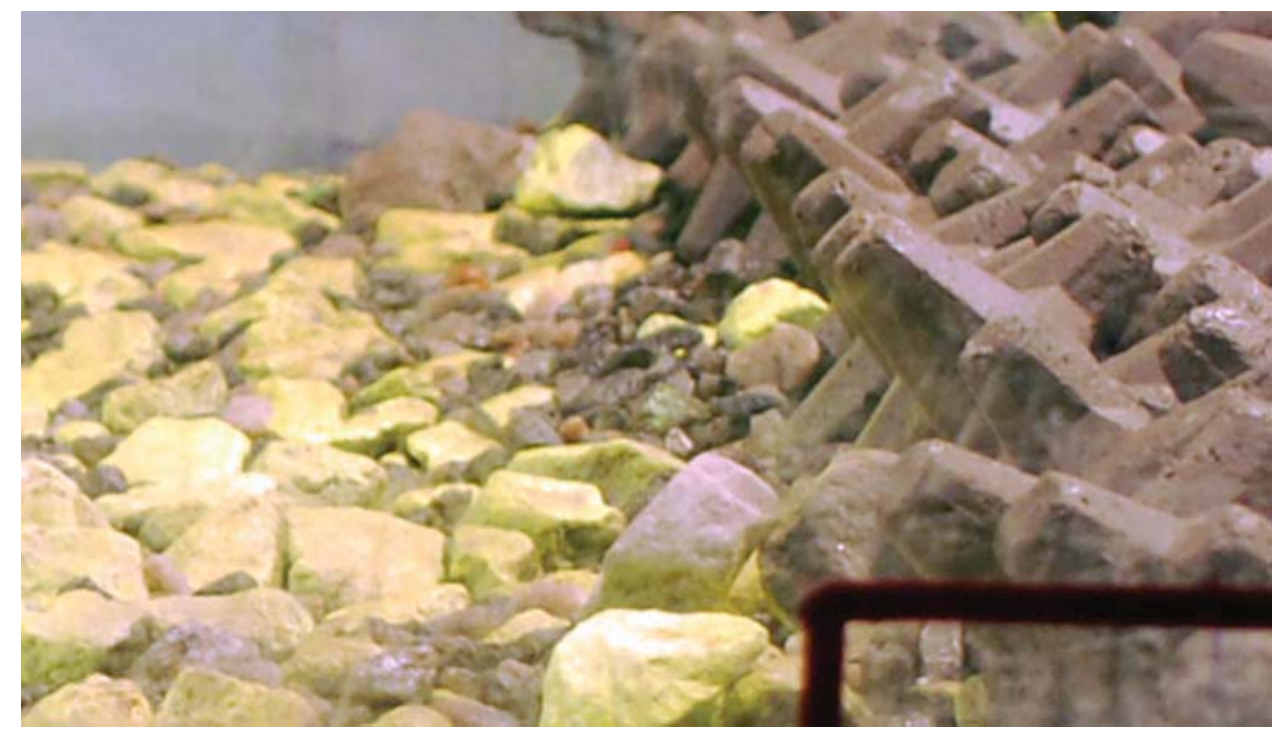

Figure 13: Outermost row of toe reinforcement - showing accumulation of smaller quarry run rock after test

\section{CONCLUSIONS}

Use of CORE-LOCTM single layer concrete armour units as alternative to rock armour placed in double layer as toe reinforcement in front of the primary armour toe on a rock armour apron has been validated by prototype scale dry trial and 1:48 scale 2D physical hydraulic modelling.

The dry trial established that an "alternate opposing cannon" pattern placement is practical for construction and readily achieves good results in the field.

Placing CORE-LOCTM units as toe reinforcement is done in rows going seawards, after placing the primary armour toe. The same grid spacing used for the primary armour can be used for the toe reinforcement to generate individual unit placing positions.

Number of rows of units used as toe reinforcement was varied in the flume testing from two to four. Units were stable in all tests. In each case dislodged smaller material coming from the outer apron accumulated at the foot of the outermost toe reinforcement row, indicating the stability of this detail.

In order to achieve equivalence to the originally designed rock armour toe reinforcement, three rows of CORE-LOC ${ }^{\mathrm{TM}}$ units were required.

\section{ACKNOWLEDGEMENTS}

The authors thank the Sri Lanka Ports Authority and the Asian Development Bank for publication of this paper, and Concrete Layer Innovations for their input and guidance on the development of suitable pattern placement for the toe reinforcement.

\section{REFERENCES}

Kyle, J. 1886. Paper 2164 Colombo Harbour Works, Ceylon, Concrete as applied in the Construction of Harbours, Proceedings of the Institution of Civil Engineers Vol. lxxxvii. Session 1886-87 Part I (Forrest J. (ed))

Van der Meer ${ }^{(103)}$, d'Angremond and Gerding 1995. Coastal Engineering Manual, EM 1110-2-1100 Part VI, 2003, Table VI-5-46, p. VI-5-107

Baart, S., Ebbens, R., Nammuni-Krohn, J., and Verhagen, H.J. 2011. Toe rock stability for rubble mound breakwaters, Proceedings of the 32nd International Conference on Coastal Engineering, ASCE http://journals.tdl.org/ICCE/article/view/1288 